Article

\title{
Integrating SDGs in Higher Education-Case of Climate Change Awareness and Gender Equality in a Developing Country According to RMEI-TARGET Strategy
}

\author{
Mona Nabil Demaidi ${ }^{1, *(1)}$ and Khaled Al-Sahili $2,3, *$ (D) \\ 1 Computer Engineering Department, Faculty of Engineering and Information Technology, \\ An-Najah National University, Nablus P.O. Box 7, Palestine \\ 2 Civil Engineering Department, Faculty of Engineering and Information Technology, \\ An-Najah National University, Nablus P.O. Box 7, Palestine \\ 3 Réseau Méditerranéen des Ecoles d'Ingénieurs, Ecole Centrale Marseille, Technopôle de Château Gombert, \\ 38 rue Frédéric Joliot Curie, CEDEX 20, 13451 Marseille, France \\ * Correspondence: m.demaidi@najah.edu (M.N.D.); alsahili@najah.edu (K.A.-S.)
}

check for updates

Citation: Demaidi, M.N.; Al-Sahili, K. Integrating SDGs in Higher Education-Case of Climate Change Awareness and Gender Equality in a Developing Country According to RMEI-TARGET Strategy. Sustainability 2021, 13, 3101. https://doi.org/10.3390/su13063101

Academic Editor: Anastasios Michailidis

Received: 29 January 2021

Accepted: 5 March 2021

Published: 11 March 2021

Publisher's Note: MDPI stays neutral with regard to jurisdictional claims in published maps and institutional affiliations.

Copyright: (c) 2021 by the authors. Licensee MDPI, Basel, Switzerland. This article is an open access article distributed under the terms and conditions of the Creative Commons Attribution (CC BY) license (https:/ / creativecommons.org/licenses/by/ $4.0 /)$.

\begin{abstract}
Universities play an essential role in spreading climate change awareness. However, slight information on climate change and environmental issues had been integrated into the curricula. Moreover, minimal research had been carried out to understand university role in spreading awareness, and students level of awareness and daily behaviour towards climate change, especially in developing countries. This paper aims to investigate the aforementioned issues. An experimental study was carried out on 448 undergraduate students enrolled at An-Najah National University Palestine. The study aimed to examine students' knowledge and daily behaviour towards climate change, and the important role the university and students' societies play in terms of spreading and enhancing awareness. The results revealed that female and male students had a non satisfactory interest level in environmental topics and activities, and gender equality did not seem to be an issue. Moreover, female students tend to have a significantly lower level of awareness on climate change compared to male students. On the other hand, being an engineering students or a member in students' societies had a positive impact on students' level of awareness and especially females. The results revealed that female students who are enrolled in the engineering faculty or members of students' societies had a significantly higher level of awareness compared to female students who are enrolled in other faculties or not members of students' societies. In general, students had a low level of awareness regardless of gender or faculty and universities should offer undergraduate students and especially female students' opportunities to learn more about climate change by integrating climate change topics into higher education. Moreover, universities should support extracurricular activities held by student societies, and some of these activities should be directed towards environmental and climate change issues. This study entails the activities of the Mediterranean Gender Equality Community of Practice co-created by the Mediterranean Network of Engineering Schools (RMEI), where An-Najah University is an active member, with the support of the EU TARGET project entitled 'Taking a reflexive approach to gender equality at Institutional transformation'.
\end{abstract}

Keywords: climate change; awareness; sustainable development goals; university students; behaviour; RMEI; TARGET

\section{Introduction}

The United Nations Department of Development and Social Affairs established 17 sustainable development goals (SDGs); among which are Quality Education (SDG 4), Gender Equality (SDG 5), and Climate Action (SDG 13) that are related to the scope of this paper. Climate change is a global issue facing the earth we live on. It is caused by global warming that is driven by human emissions of greenhouse gases, and the large 
shifts in weather patterns. Since the mid-20th century the rate of human impact on earth's climate system and the global scale of that impact have been unprecedented. The most important driver has been the emission of greenhouse gases, the majority of which are carbon dioxide $\left(\mathrm{CO}_{2}\right)$ and methane, which are predominantly produced by the burning of fossil fuels, with contributions from agriculture, deforestation, and industrial processes [1]. The hazard of global warming is one of the most important and critical problems of the world $[2,3]$.

The United Nations-Peace, dignity, and equality on a healthy planet website establishes that the impacts of climate change are global in scope and unprecedented in scale. This has created shifting weather patterns that threaten food production, and rising sea levels that increase the risk of catastrophic flooding [4].

Research indicates that climate change threatens countries economic bases and would impact agricultural and tourism developments [5-7]. The research revealed that southern Africa might be losing its unspoiled tourism attractions due to the increase of climate change impact. At the same time, little research has been conducted to understand better the attitudes and information levels of citizens, especially young adults worldwide, particularly in developing countries, regarding these issues [8]. Therefore, universal efforts should collaborate to reduce carbon footprint to ease the greenhouse effects. Saving energy consumption in our daily life and using renewable energy sources can surely help; however, it all starts with raising awareness [9]. The role of universities in this regard is critical [10-12]. There is an increasing level of attention to the problem worldwide; however, many believe that the applied efforts are still not robust and similar across the globe [13-15]. Therefore, more intensive effort and cooperation among global universities is an urgent matter [16].

The rate of literacy has been increasing worldwide including the developing countries since the 20th century, and many more girls are in school than before. Enrolment in primary education in developing countries has reached $91 \%$, and 1 in four girls is not in school [4]. At the college level quality education does not only mean enrolment and graduation rate, but also includes the long lasting knowledge and skills level students attain at graduation. One of knowledge items related to the scope of this paper, is the knowledge and awareness regarding climate change issues, impacts, and solutions.

Nowadays, more universities worldwide are concerned about integrating the SDGs in their system for various reasons. These include, in addition to the global interest, social and societal responsibilities as well as their international ranking [15]. As a result, highereducation institutions recognise the crucial role they can play in raising awareness and understanding of climate change amongst their students. This is generally done through educational and research programs, as well as direct and indirect activities.

It is currently common among many universities that females constitute more than $50 \%$ of students' enrolment, even in developing countries [17]. However, this does not necessarily mean that gender equality (GE) has been achieved at the university and market levels $[18,19]$. And how much the quality education and awareness of climate change related to gender is a question that remains to be answered. Therefore, integrating the aforementioned three SDGs (SDG 4, SDG 5, and SDG 13) at the university level is the target of this paper.

It is critical that formal and informal education help improve the public's understanding of the climate change challenges, and creates a difference in preparing current and future generations to act to limit the effect of climate change and respond to those challenges [17]. This does not necessarily mean creating a major component of educational curricula focused on climate sciences and climate change as this might be achieved by the fundamentals of each systems science. Including climate change education in the program might achieve certain level of understanding among students; however, students attained skills and awareness are likely to achieve better results. For example, students (or graduates) should be able to make well-reasoned decisions in their daily life taking into consideration the environmental impacts, as well as climate change. 
Research has shown that students have many misconceptions regarding climate change. Students generally do not understand the translation of global warming into climate change [17]. There were differences among students from different countries around the world in terms of their knowledge of different aspects of climate change. The research also recognised the variation of increased conceptual knowledge or improved decision making in the educational programs when assessing the best approaches to climate education. The study also highlighted that aspects of climate change are integrated and cross-disciplinary, and at the same time students are very much influenced by their families and societies outside the school.

People ought to better understand climate change and its effect and what be done to cope with it. It starts with understanding the causes of global warming and its effects. Therefore, it is of great importance to consider education and awareness through the inclusion of global warming issues in educational curricula as well as clearing misconceptions students and people have about global warming. It is the most effective way to raise the environmental consciousness among nations [20-23].

The majority of the literature focused on students' awareness at the school's level (elementary and high school) and these were mostly conducted in the developed countries; limited studies were conducted in the developing countries including Arab countries. A study conducted in the United Arab Emirates University (UAEU) indicated that awareness of environment, global warming, and greenhouse effect among science students is expected to be one of the highest [24]. The study found that students from the college of Science and Food and Agriculture were more aware of the use of biotechnology and its environmental impact as compared to other students. On the other hand, the study concluded that students mainly gained their knowledge through the general education rather than from the university education.

Freije, et al. [25] studied the level of awareness among the University of Bahrain science students regarding global warming and greenhouse effect, with a sample size of 143 students. The study showed that more than half the students have the knowledge about global warming, and fourth year students have better knowledge than freshmen students who obtained their knowledge from the school system and the general media. Furthermore, there were variations in the awareness level among different science majors such that biology students have the highest level and math students have the lowest among the science students. This was attributed to the fact that the academic curriculum where the biology includes a number of compulsory as well as elective courses that include aspects related to the environment and global warming. The study revealed that strategic intervention helped to enhance the media coverage on global warming and environmental issues. Moreover, government needs to support programs aimed at educating the public on global warming and environmental issues. The study also recommended that considerable efforts should be done to integrate environmental concepts into the university curriculum irrespective of the academic study specialization, as well as through extra curricula activities.

Moswete, et al. [26] conducted a study to compare the attitudes of undergraduate students regarding climate change and environmental issues at the University of Botswana in Gaborone and the U.S. Naval Academy (USNA) in Annapolis, Maryland, USA. The study found large differences among the students from the two universities. Only a quarter of the USNA students viewed climate change as a critical problem today, and half of students thought that climate change would be a future problem. Students from Botswana had higher level of awareness of the seriousness of the climate change related problems and environmental issues in the current state. On the other hand, there were large differences between students of environmental sciences and business majors in the University of Botswana. The study suggested that more information on climate change and environment should be integrated into courses, subjects, or programs in the higher education system across developing and the developed countries. In terms of climate change and the natural environment, students living in urban centres need to be introduced to the rural environment through field-based courses or subjects for practical activities. 
Filho, et al. [16] indicated that despite the existence of scientific evidence, scepticism about climate change is still a popular trend worldwide. The authors further indicated that only a few universities integrate climate change into their curricula, which might lead to the concern that leaders of these universities are also sceptical about the issue and its seriousness. The study summarised the different experiences in climate action in selected universities from different parts of the world, which showed the importance of sharing experiences and efforts at the regional or international levels. It showed that the vast majority of surveyed students believe that climate change is happening and humans have a lot to do with it; at the same time, they believe that their universities are not doing much at their policy level. The study also showed that the perception of students towards climate change clearly varied by region such that South America, Africa, and Asia scored the lowest, while Europe, North America, and Oceana scored higher. The authors suggested that universities are yet to fully incorporate climate related issues into their programs, more efforts in respect of policy-making are needed, and these policies should address issues related to vulnerability, especially among poor communities.

Climate change increases gender inequality, decreases the capacity of women to be financially independent, and has an overall negative effect on women's social and political rights, especially in highly agricultural-based economies. However, the study of gender in climate change is not confined to women. It also means not only applying a binary male/female analysis method to quantitative data sets, but also scrutinizing discursive constructions that form climate change-related power relations [27]. The Paris Agreement of the United Nations Framework Convention on Climate Change, ratified by 185 countries, established a global goal for adaptation to climate change, and it also acknowledges the importance of gender equality and calls for climate action to be gender-responsive [28]. In many countries women are under-represented in decision-making in areas relevant to climate change adaptation. Therefore, the research acknowledges that in order to ensure that investments are targeted where they are needed most, effective adaptation should consider the differing needs of women, men, and marginalised groups.

This was further verified that women commonly face higher risks and greater burdens from the impacts of climate change in situations of poverty, and the majority of the world's poor are women [29]. There are evidences that women play an important role in supporting households and communities to mitigate the effects and adapt to climate change [30,31]. David [17] established that gender is being introduced into the climate debate at an increasing rate. Geographers and feminist scholars are highlighting that climate change is felt unevenly among social strata that has been disadvantaged and marginalised with bearings along gender, race, and class lines. The author further stated that the absence of an inter-sectional lens in the discourse on gender and environment causes the development of gender to be mediated by predominantly white western bodies in climate negotiations.

Low [32] reviewed the gender literature on climate change and REDD+ projects to elaborate on gender-specific subordination of women. The author concluded that intersectional feminist perspectives showed that indigenous and marginalised women play a crucial role in engaging with climate change. The study argues that the genderenvironment-climate interconnection is more complex and that greater attention is paid to a nuanced, context-sensitive, and power-sensitive examination of women's empowerment and gender equality in the context of climate change.

At the local Palestinian level, the issue of climate change awareness at the university level has not been investigated except as part of academic course work where the level of environmental awareness among students were explored. It revealed that participation in environmental activities or reading environmental subjects among Palestinian students is generally low.

Based on the previous studies, it is concluded that universities in developing countries are somewhat aware of the importance of SDGs and especially climate change. However, minimal work had been carried out to integrate climate change topics into the educational curriculum; this affects students level of awareness. At the same time, the literature has not 
addressed the issue of gender as related to climate change at the university level. Therefore, this paper aims to investigate the level of university students' awareness of, and involvement in, activities and issues related to climate change. The objectives of this research are to examine students' level of awareness, daily behaviour towards climate change, and student societies' and organisations' role in terms of enhancing the understanding of climate change. Since the authors are associated with the Faculty of Engineering and Information Technology (FEIT), the research compares between students from the FEIT and other faculties. This all will be put into the gender equality perspective at An-Najah National University (NNU), as a case study for Palestinian universities and in a developing country.

This study entails the activities of the Mediterranean Gender Equality Community of Practice co-created by the Mediterranean Network of Engineering Schools (RMEI), where NNU is an active member, with the support of the EU TARGET project entitled 'Taking a reflexive approach to gender equality at Institutional transformation'. With about 30 Universities-members, the Mediterranean Engineering Schools Network (RMEI) is the most active network on gender equality in the Mediterranean area. Supported by the HORIZON2020 'Taking a Reflexive Approach to Gender Equality for Institutional Transformation' (TARGET) project in conceptualizing gender equality learning and system change, the network has created a Community of Practice that is Engineering- and other STEM- specific considering the systemic view of SDG5 horizontally connected to all SDGs and Climate Change (see Figure 1) [33,34].

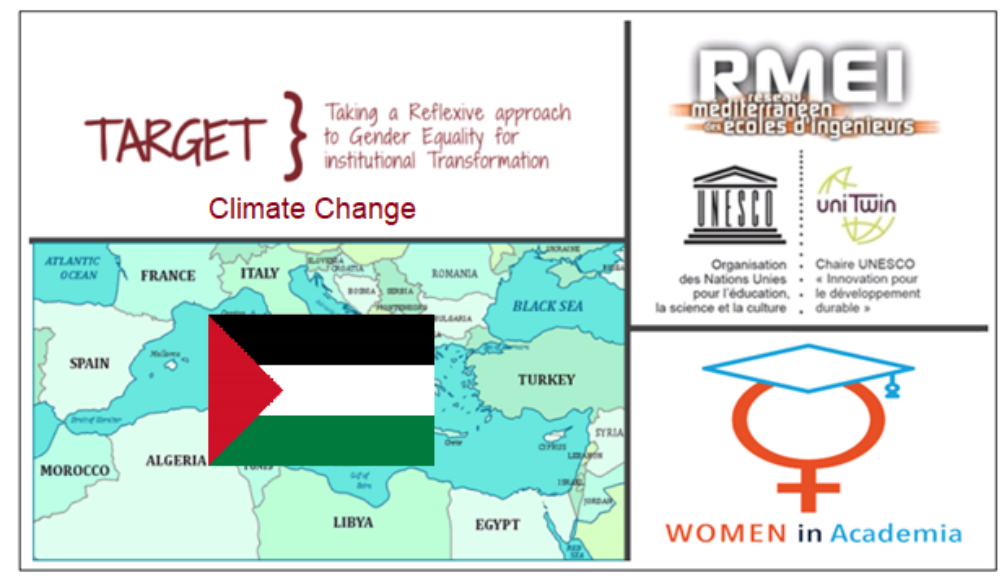

Figure 1. Conceptual Representation of Integrating SDGs in Higher Education-according to RMEITARGET Vision.

This paper is organised as follows. After the introduction and a review of previous work, Section 2 describes the study methodology. Section 3 presented the university background. The results are analysed and discussed in Section 4. Finally, a conclusion of the paper and future work are provided in Section 5.

\section{Study Methodology}

This paper aims to study the awareness of undergraduate students on climate change, and the role universities and students' societies play to help spread awareness by taking gender and faculty factors into account. The study was carried out over two consecutive academic years in two stages. This study aims to answer the following research questions by taking faculty and gender factors into account:

- What is students' level of awareness on climate change?

- Are students playing a key role in reducing the effects of climate change?

- Are universities and students' societies playing an effective role in terms of enhancing students understanding of climate change?

In addition to the review of selected literature related to the scope of this study, the study was conducted in two stages. The first stage was a preliminary study aimed to exam- 
ine students' interest in environmental topics and activities, and their daily application to environmental practices. This was conducted through an on-line survey of 200 undergraduate students enrolled at NNU. Students voluntarily answered a questionnaire, which was published via the university portal. Based on results of the preliminary study, the second stage was launched with a more detailed study focusing on climate change aiming to assess students' knowledge and daily behaviour towards climate change. A total of 250 students voluntarily filled in a knowledge test (quiz) and a questionnaire, which was also published via the university portal. Moreover, the role universities and students' societies play to enhance students' awareness of climate change was examined. The data collected using the quiz and the questionnaire was analysed using SPSS [35] with 95\% confidence interval.

Furthermore, in order to better understand the results; relationships and causes, focus group sessions were held with 25 undergraduate students. Due to the large number of students, two similar focus group sessions were held, each for approximately two hours. In these sessions, students were again asked the key questions in the quiz and questionnaire. Furthermore, the quiz and questionnaire results were revealed to students, and they were requested to explain these results from their perspective and highlight justifications and causes for some key issues. At the end, students provided recommendations to improve the awareness level among students. This was further supplemented by interviewing the vice president for academic affairs (male) and two faculty deans; the dean of Faculty of Engineering and Information Technology (male) and the dean of Faculty of Educational Sciences and Teachers' Training (female).

The detailed composition of the participants in each stage is presented in the subsequent sections of this study.

\section{University Background}

The following is a brief background about An-Najah National University (NNU) and its interest in the SDGs including the climate change and gender equality, with a focus on the Faculty of Engineering and Information Technology (FEIT). An-Najah National University is one of the largest universities in Palestine with more than 23,000 students. It offers several bachelor and graduate degree programs in various disciplines. In year 2020, in order to show its commitment and to spread awareness among university's community, NNU posted the 17 SDGs in several key places all over its four campuses in both Arabic and English languages (see Figure 2).

Universities and educational institutions in Palestine are aware of the importance of environmental sustainability, and specifically climate change [36,37]. This is due to the fact that some of the universities ranking system measures universities' research on climate change, their use of energy, and their preparations for dealing with the consequences of climate change [38]. Table 1 shows An-Najah National University performance in Times Higher Education World University Ranking. The ranking assesses universities against 11 out of 17 Sustainable Development Goals (SDGs). The ranking shows that the university is committed to achieving the SDGs and has carried out several initiatives and projects to improve its ranking. For example, the university installed solar panels on campus rooftops to produce alternative energy. Moreover, the university Energy Research Centre worked on installing free solar panels in different villages, schools, and municipalities to generate electricity [39]. 


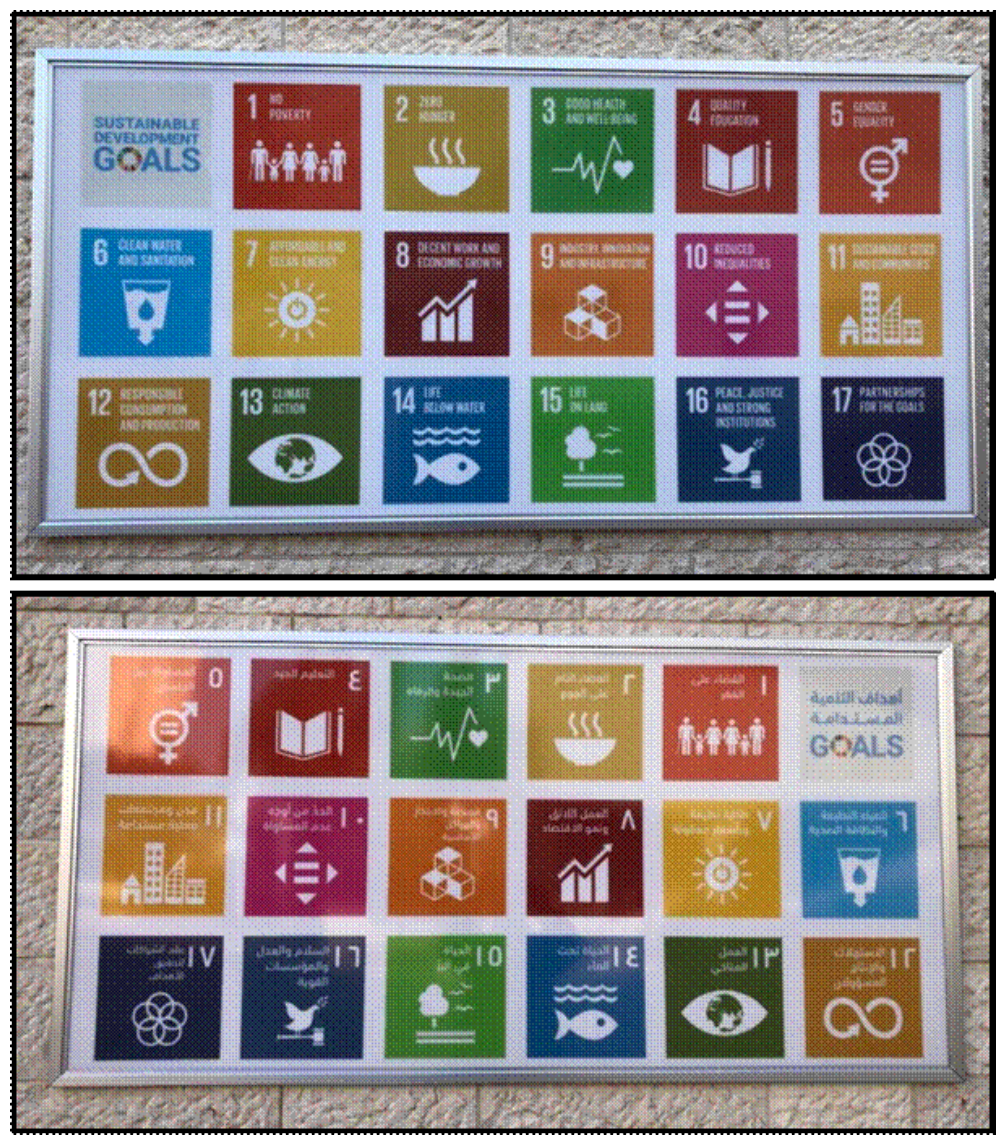

Figure 2. SDGs posts at An-Najah National university campus.

Despite the increasing interest in achieving environmental sustainability, the University has minimal integration of climate change topics in educational material, and has yet limited initiatives to help spread awareness among students.

Table 1. ANNU performance in Times Higher Education World University Rankings in 2019.

\begin{tabular}{cc}
\hline SDG & Rank \\
\hline Climate Action & $201^{+}$ \\
Clean water and sanitation & 23 \\
Affordable and clean energy & $101-200$ \\
Sustainable cities and communities & $101-200$ \\
Gender Equality & $101-200$ \\
\hline
\end{tabular}

The university is also aware of the necessity to achieve gender equality. Female students constitute $64 \%$ of the student body. Among its staff, $26 \%$ of the academics and $41 \%$ of the administrative are females, with an overall percentage of $38.5 \%$. In addition, one of the three vice presidents and two out of eleven deans are females.

Over the past few years, the number of university's female staff sent on scholarship to obtain higher degrees (masters or PhDs) has increased significantly. University records show that currently, $36 \%$ of scholars are female, while in the past this percentage was negligible.

As part of its social responsibilities, NNU is active in the gender equality issues. This is generally resembled through workshops, conferences, academic programs, and policies. Colleges, departments, staffs, and students' scientific societies are actively involved in on-campus and off-campus activities as well. The Vice President for International Cooperation's office is active in women empowerment on campus and prepared a plan to better 
activate the role of women. The university is currently working on a project to strengthen women in scientific research.

Furthermore, NNU offers a master's program in Women's Studies. The university also adopts several policies addressing gender equality, directly and indirectly. For example, the university adopts the following policies and posts them on its web site [40]: Academic Freedom Policy, Access and Participation to Study Policy, Harassment and Discrimination Policy, and Openness and Accessibility Policy. In addition, the Women's Rights Policy has several sub-policies that address the gender equality. Following the endorsement of the RMEI network (Réseau Méditerranéen des Ecoles d'Ingénieurs; French acronym for Network of Mediterranean Engineering Schools) of the Gender Equality Statement (GES) prepared by TARGET (Taking Reflexive Approach to Gender Equality for Institutional Transformation) Project, NNU was the first among the RMEI network to endorse the GES at the Council of Deans level, and posted it on its "policies" web page [41].

NNU has 11 colleges; the largest is the FEIT with 5200 students. Contrary to the common tradition worldwide, approximately half of the student body in the FEIT is female $(48.3 \%)$. Out of 18 BSc degree programs offered at FEIT, 10 of them have female majorities (above 50\%). There are several programs with females being the vast majority. For example, female students of the Telecommunications Engineering, Chemical Engineering, Urban Planning Engineering, and Architectural Engineering programs are all above 75\%. The least female enrolment is in the Mechanical Engineering and Mechatronic Engineering programs (2.4\% and $7.6 \%$, respectively). Female students in the FEIT are prominent figures among the student bodies and achieved leadership positions in the students' attainment levels in the programs.

The FEIT has several scientific societies that are student chapters of the international mother societies. The societies aim to improve students' soft and technical skills. Female students are also leaders in these societies where they occupy several positions in their administrations (Table 2). Student societies, among other things, promote diversity; they are diverse in gender, education, income, and expertise.

Table 2. Percentage of female participation in student societies.

\begin{tabular}{ccc}
\hline Students Scientific Society & Admin Staff & Members \\
\hline Institute of Industrial \& Systems Engineers (IISE) & $50 \%$ & $53 \%$ \\
American Institute of Architecture Students (AIAS) & $55 \%$ & $77 \%$ \\
Association of Energy Engineer (AEE) & $89 \%$ & $74 \%$ \\
American Society of Civil Engineer (ASCE) & $21 \%$ & $40 \%$ \\
American Institute of Chemical Engineers (AICHE) & $79 \%$ & $82 \%$ \\
Institution of Mechanical Engineers (IMechE) & $0 \%$ & $10 \%$ \\
Institute of Electrical and Electronics (IEEE) & $62.5 \%$ & $55 \%$ \\
Engineers Without Borders An-Najah (EWB) & $52 \%$ & $33 \%$ \\
\hline
\end{tabular}

In addition, female students are quite active in the various scientific organisations in and off campus. Furthermore, there are some scientific organisations that directly involve females; Women in Engineering (WIE) of the IEEE [42], Arab Women In Computing (ARABWIC) [43], and Girls in Tech (GIT) [44]. The main aim of these organisations is to decrease the unemployment rate among the engineering females, which is high (53\%) according to the Engineers Association in Palestine, and close the gap between the private and academic sectors. Furthermore, several activities held by these societies and organisations dealt with various environmental and sustainability issues. Therefore, it is expected that these student leaderships have greater appreciation and more awareness regarding the climate change issues, which will be investigated in this research. 


\section{Results and Discussions}

\subsection{Preliminary Study}

This section presents the preliminary study, which aimed to examine students environmental awareness by their interest in environmental topics and activities, and their daily environmental practices. The study was carried out in 2019/2020 on 200 undergraduate students enrolled at NNU, $20 \%$ of students were from FEIT and $58.5 \%$ of students were females. Students voluntarily answered a questionnaire, which was published via the university portal. The questionnaire consisted of seven questions. The results of the preliminary study are shown in Table 3. The results clearly indicate that regardless of faculty and gender, the level of environmental awareness among female and male students is unsatisfactory. Students have minimal interest in reading environmental topics, attending environmental events and participating in activities and societies which focus on environment. Moreover, the majority of students do not apply environmental practices such as waste recycling.

Table 3. Environmental awareness-preliminary study.

\begin{tabular}{cccc}
\hline Question & Yes & Maybe & No \\
\hline Do you read or watch environmental topics & $24.5 \%$ & $56.5 \%$ & $19.0 \%$ \\
\hline Do you attend environmental events & $38.0 \%$ & $13.5 \%$ & $48.5 \%$ \\
\hline Do you participate in environmental activities & $32.0 \%$ & $7.5 \%$ & $60.5 \%$ \\
\hline $\begin{array}{c}\text { Are you interested in participating in associations or } \\
\text { organisations related to the environment? }\end{array}$ & $28.0 \%$ & $26.0 \%$ & $46.0 \%$ \\
\hline Do you consider buying products made of recyclable materials? & $10.0 \%$ & $21.0 \%$ & $69.0 \%$ \\
\hline Do you use recyclable bags for shopping? & $9.0 \%$ & $12.0 \%$ & $79.0 \%$ \\
\hline Do you apply waste recycling? & $7.0 \%$ & $20.0 \%$ & $73.0 \%$ \\
\hline
\end{tabular}

The preliminary study emphasises the importance of increasing students' environmental awareness. To help achieve this, a detailed experiment was carried as presented in the subsequent sections.

\subsection{Students' Level of Awareness on Climate Change}

The second phase of the study aims to examine students' knowledge on climate change, behaviour towards climate change, and the current role university and students' societies are playing to help reduce climate change.

Lack of awareness is a significant barrier to climate change adaptation in developing countries [45]. Therefore, it is essential to increase awareness by enhancing knowledge to address and form global actions on climate change [46,47]. This section presents students' overall level of awareness on climate change which is measured using a quantitative method through the knowledge test (quiz) that consisted of seven multiple choice questions and was marked out of 100 (see questions in Appendix A), a questionnaire, which consisted of five 5-point Likert scale. After that, a qualitative method was used through the discussions with the focus group and interviews with the key administrative/academic staff.

A total of 248 undergraduate students volunteered to take part in the experiment in $2020 / 2021$ academic year, among which $64.1 \%$ were females, $62.1 \%$ were from the FEIT, and $37.9 \%$ were members of student societies. The students' composition according to their majors is shown in Table 4. Students' level of awareness was measured using a knowledge test and a questionnaire. After that, the research results were discussed with a focus group, which consisted of 25 students, among which 13 students were from the FEIT and 12 students from non-engineering faculties. The focus group consisted of 17 female students and 8 male students, in which 14 out of 25 were members of students' societies. 
Table 4. Distribution of participants among university faculties.

\begin{tabular}{cc}
\hline Faculty & Percentage of Students \\
\hline Faculty of Engineering and Information Technology (FEIT) & $61.4 \%$ \\
Faculty of Medicine and Health Sciences & $24.7 \%$ \\
Faculty Of Educational Sciences And Teachers Training & $1.7 \%$ \\
Faculty of Fine Arts & $4.4 \%$ \\
Faculty Of Economics And Social Studies & $4 \%$ \\
Faculty of Law & $3.8 \%$ \\
\hline
\end{tabular}

Figure 3 shows that the quiz mean grade was $42.57 \%$ and $50 \%$ of students obtained a grade below $40 \%$. This indicates that students overall level of awareness on climate change is low. The focus group emphasised that the low level of awareness is due to the fact that students obtain minimal information on climate change from educational programs. Moreover, most of them agreed that the knowledge they have on climate change is from the school curriculum and prior to joining the university.

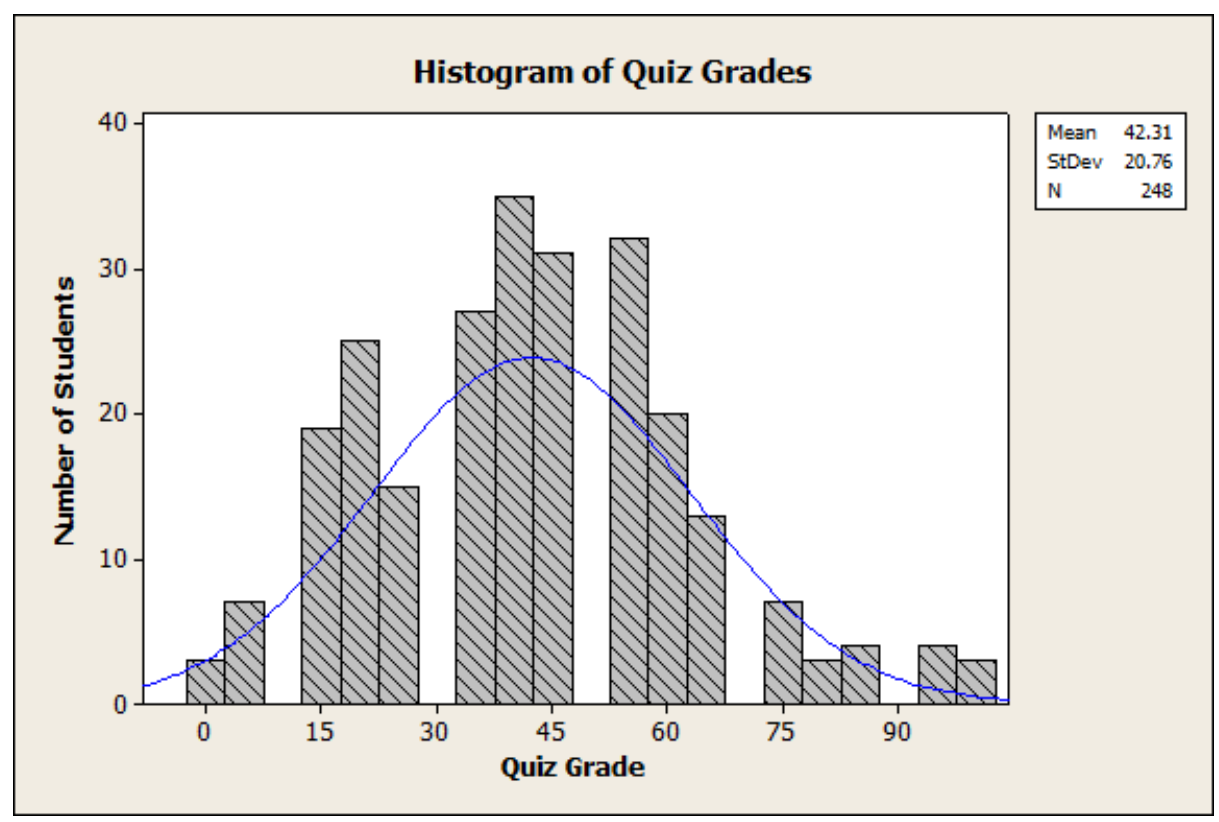

Figure 3. Distribution of students' level of awareness on climate change.

Further analyses were carried out using independent sample $t$-test to examine effect of faculty and gender factors on students' level of awareness. Figure 4 shows that there is a significant difference in the mean quiz grade between students in engineering and non-engineering faculties $(\mathrm{t}=2.9, p$-value $<0.05, \mathrm{CI}=95 \%)$. Students in engineering faculty tend to have higher level of awareness (mean $=45.5$ out of 100 ). However, the level of awareness is not satisfactory and significant knowledge gaps exist. Engineering students are generally from among the highest grade point average students in the high school general exam, which might explain their relatively higher level of awareness as compared to other students. The focus group and the two deans agreed with the results and stated that engineering programs tend to be more interdisciplinary and project-based compared with other programs. This helps students improve their knowledge in different sectors including climate change and consequently improve their awareness.

The results also revealed that the level of awareness differentiates between female and male students (see Table 5). Female students had a significantly lower level of awareness compared to male students $(\mathrm{t}=-2.68, p$-value $=0.01, p$-value $<0.05, \mathrm{CI}=95 \%)$. No significant difference had been found between male students in engineering and nonengineering faculties $(t=-0.49, p$-value $>0.05, C I=95 \%)$. However, Table 6 shows that 
female students in engineering had a significantly higher level of awareness compared to female students in non-engineering programs $(\mathrm{t}=3.84, p$-value $<0.05, \mathrm{CI}=95 \%)$. The focus group, as well as the two deans stated that due to cultural issues, female students have limited access to knowledge resources outside the university compared to male students who have higher involvement with the surrounding community and are constantly exposed to issues and obstacles the community face. This might affect female students' level of awareness negatively. The focus group also agreed that being an engineering student tends to have a positive effect on female students' level of awareness compared with no effect on male students' level of awareness. The group argued that females in the engineering are exposed to multidisciplinary problem solving cases compared to nonengineering female students. On the other hand, male students had no difference in the level of awareness, regardless the faculty they are enrolled in; male students have more access to knowledge resources outside the university and have relatively high involvement with the surrounding community.

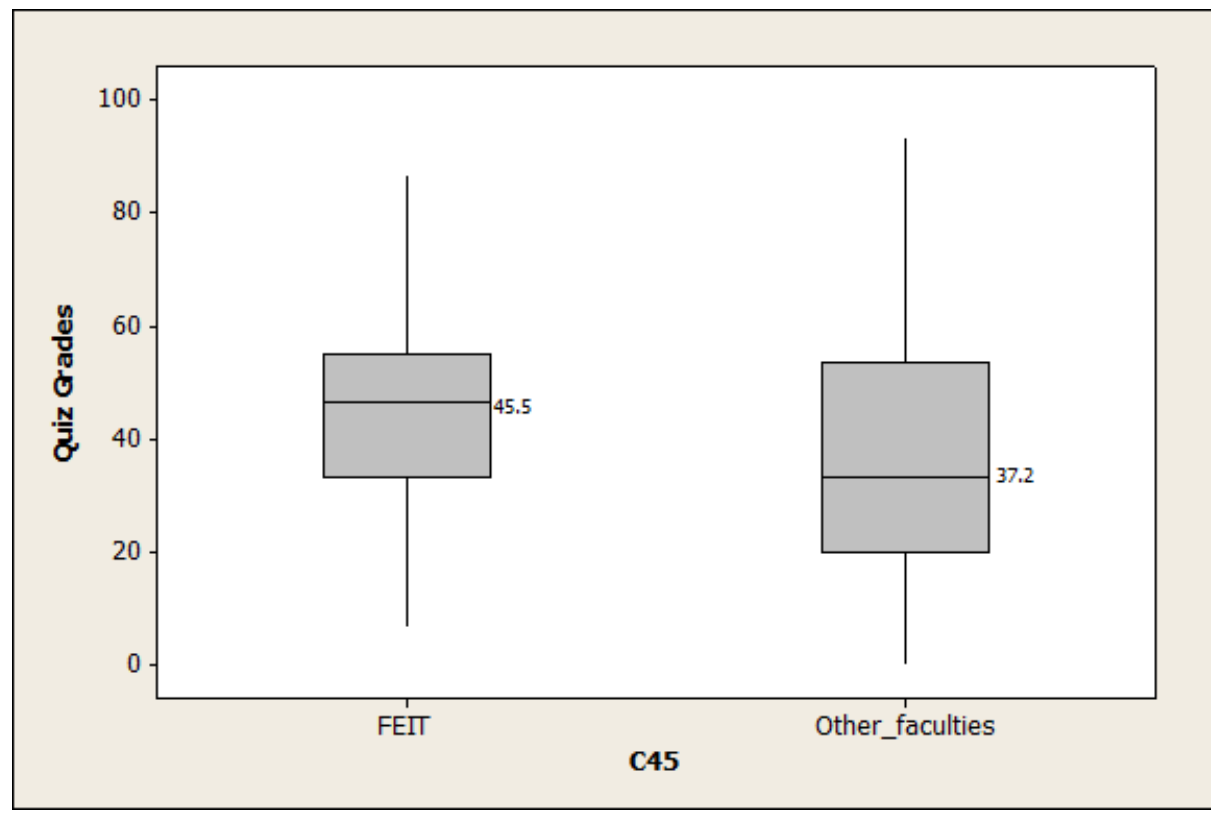

Figure 4. Engineering and non-engineering level of awareness on climate change.

Table 5. Difference in level of awareness between female and male students.

\begin{tabular}{cccc}
\hline Gender & Number of Students & Mean Performance & Standard Deviation \\
\hline Female & 159 & 39.6 & 21.4 \\
Male & 89 & 47.1 & 18.7 \\
\hline
\end{tabular}

Table 6. Students level of awareness on climate change based on faculty and gender.

\begin{tabular}{ccccc}
\hline Faculty & Number of Students & Gender & Mean Performance & Standard Deviation \\
\hline Engineering & 94 & Female & 44.8 & 24 \\
Engineering & 60 & Male & 46.4 & 21 \\
Non Engineering & 65 & Female & 32.1 & 19.0 \\
Non Engineering & 29 & Male & 48.5 & 17 \\
\hline
\end{tabular}

Students level of awareness on climate change was also measured using a 5-point Likert scale questionnaire. Table 7 , illustrates the median of students' responses to five statements. The results revealed that students do not have a clear definition of climate change (Median $=3$ ). Moreover, they tend to disagree on following and searching for 
climate change topics. On the other hand, students are aware and agree that individuals' actions are essential to reduce climate change. Moreover, they are willing to learn best practices to help reduce and mitigate climate change. This was reiterated through the focus group sessions.

Table 7. Qualitative assessment of 248 students' awareness on climate change.

\begin{tabular}{cc}
\hline Climate Change & Median \\
\hline I can define climate change & 3 \\
I follow and search environment and climate change topics & 2 \\
Behaviour and actions of each individual can help prevent climate change & 4 \\
Climate change affects me and my surrounding negatively & 4 \\
I am willing to learn best practices to help reduce and prevent climate change & 4 \\
\hline
\end{tabular}

Further analysis were carried out using Mann-Whitney $\mathrm{U}$ test as shown in Table 8. The results revealed that there is a significant difference between female students in engineering and non-engineering faculties in terms of following and searching for environment and climate change topics ( $\mathrm{U}=4060, p$-value $<0.05, \mathrm{CI}=95 \%$ ). However, no significant difference was found in students' awareness level on climate change between female and male students or between engineering and non-engineering faculties. Regardless of faculty or gender, students tend to have no clear definition of climate change (Median $=3$ ). However, students have good awareness on the importance of individual actions towards reducing climate change. This was also clear in the focus groups.

Table 8. Students climate change awareness median in engineering vs non engineering faculties based on gender.

\begin{tabular}{|c|c|c|c|c|}
\hline Climate Change Statement & $\begin{array}{c}\text { Female } \\
\text { Engineering } \\
\text { Students }\end{array}$ & $\begin{array}{c}\text { Female } \\
\text { Non-Engineering } \\
\text { Students }\end{array}$ & $\begin{array}{c}\text { Male } \\
\text { Engineering } \\
\text { Students }\end{array}$ & $\begin{array}{c}\text { Male } \\
\text { Non-Engineering } \\
\text { Students }\end{array}$ \\
\hline I can define climate change & 3 & 3 & 3 & 3 \\
\hline $\begin{array}{l}\text { I follow and search } \\
\text { environment and } \\
\text { climate change topics }\end{array}$ & 2 & 3 & 3 & 3 \\
\hline $\begin{array}{l}\text { Behaviour and actions } \\
\text { of each individual } \\
\text { can help prevent climate } \\
\text { change }\end{array}$ & 4 & 4 & 4 & 4 \\
\hline $\begin{array}{l}\text { Climate change affects } \\
\text { me and my } \\
\text { surrounding negatively }\end{array}$ & 4 & 4 & 4 & 4 \\
\hline $\begin{array}{l}\text { I am willing to learn } \\
\text { best practices } \\
\text { to help reduce and } \\
\text { prevent climate change }\end{array}$ & 4 & 4 & 4 & 4 \\
\hline
\end{tabular}

Students were also asked whether they are aware that climate action is one of SDGs. Most of students (61.3\%) did not know that climate action is one of the goals. However female students had a higher percentage $(65.4 \%)$ than male students $(53.9 \%)$. The focus group had similar awareness regarding the climate action; they stated that they had noticed the SDGs posts across the university campuses, but had minimal knowledge about SDGs and climate action as one of SDGs goals. 
The overall results obtained in this section revealed that students had low level of awareness on climate change. The results are consistent with the results in [48], which stated that more work is needed in educating engineering students on climate change and integrating climate change into higher education. Moreover, universities should offer undergraduate students and especially female students the opportunities to learn more about climate change. Since according to Lee et al. awareness and education on climate change are strongly linked [49].

\subsection{Students Behaviour Towards Climate Change}

Several educational interventions can be used to address climate change lack of knowledge and awareness, both inside [50] and outside of the classroom [51]. However, having knowledge and awareness on climate change does not guarantee action to address the issue in the future [52]. Students must realise that their behaviour contributes to climate change, and it must align with motivation for action to occur [53]. To study the extent of students' awareness on climate change, this section examines students' daily behaviour towards four sectors, which contribute to climate change (transport, food, energy, and materials) $[54,55]$.

Using public transportation for commuting in cities instead of individual vehicles, and walking and cycling help reducing carbon emissions [54,56]. Table 9 illustrates that $55.6 \%$ of students use public transportation and only $9.7 \%$ use walking and cycling. The results are expected since Palestine lack proper and continuous walking and cycling infrastructure [57]. On the other hand, more than one third of students use private vehicles on a daily basis, which contributes negatively to climate change.

Table 9 also shows that students' daily behaviour towards food waste and minimising food loss contributes to reducing climate change. The vast majority of students (91.5\%) either keep food for next day or feed it to pets.

Students had similar attitude towards energy since more than $50 \%$ of students stated that if affordable they are willing to use solar panels at home. Moreover, $59.27 \%$ of students use energy efficient lightening at their households.

On the other hand, more than $60 \%$ of students prefer paper books and use paper bags. Although the use of paper bag is environmentally better than using plastic bags; however, using paper books instead of electronic copies is worse; both have a negative effect on climate change and increase carbon emission.

In summary, female and male students tend to have similar behaviour towards climate change. However, awareness sessions should to be carried out to help them understand how their actions contribute to climate change.

\subsection{The Role Universities and Students' Societies Play in Enhancing Understanding of Climate Change}

This section examines the university and students' societies role in enhancing students ${ }^{\prime}$ understanding on climate change. Table 10 shows that female and male students do not consider the university and students' societies as an essential source of information on climate change. Instead, they use internet, social media, and news to learn more about climate change; this was further confirmed by the focus groups. These results are consistent with Figure 5, which shows that $95.9 \%$ of students agreed that they did not enrol in a course at the university that covers environmental issues or climate change topics. 
Table 9. Students' behaviour towards climate change.

\begin{tabular}{ccccc}
\hline Question & Category & $\begin{array}{c}\text { Overall } \\
\text { Percentage }\end{array}$ & $\begin{array}{c}\text { Female } \\
\text { Percentage }\end{array}$ & $\begin{array}{c}\text { Male } \\
\text { Percentage }\end{array}$ \\
\hline & Public transportation & $55.6 \%$ & $59.7 \%$ & $48.3 \%$ \\
What is you daily & Private transportation & $34.7 \%$ & $32.7 \%$ & $38.2 \%$ \\
transportation method? & Walking & $8.5 \%$ & $6.3 \%$ & $12.4 \%$ \\
& Cycling & $1.2 \%$ & $1.3 \%$ & $1.1 \%$ \\
\hline What do you do & Throw it away & $8.5 \%$ & $8.2 \%$ & $9.0 \%$ \\
with your leftover food? & Keep it and use it next day & $66.9 \%$ & $66.0 \%$ & $68.5 \%$ \\
If affordable, will you use & Use it to feed my pets & $24.6 \%$ & $25.8 \%$ & $22.5 \%$ \\
solar panels at your home? & Yes & $56.0 \%$ & $61.6 \%$ & $46.1 \%$ \\
\hline Do you use energy efficient & No & $44.0 \%$ & $38.4 \%$ & $54.0 \%$ \\
lighting (LED) in your household? & Yes & $59.3 \%$ & $42.8 \%$ & $37.1 \%$ \\
\hline Do you prefer paper books & No & $40.7 \%$ & $57.2 \%$ & $62.9 \%$ \\
\hline or e-books? & Paper books & $66.1 \%$ & $75.5 \%$ & $49.4 \%$ \\
Do you prefer to use & E-books & $33.9 \%$ & $24.5 \%$ & $50.6 \%$ \\
\hline plastic bags or paper bags? & Plastic bags & $39.5 \%$ & $32.7 \%$ & $51.7 \%$ \\
\hline
\end{tabular}

The results indicate that the university has a weak contribution towards spreading climate change awareness among students. The focus group agreed that the university has minimal contribution towards spreading climate change awareness since educational programs do not focus on the issue and no educational courses are developed to help spread climate change awareness. The group also stated that their knowledge on climate change was prior to university. This is consistent with the research carried out by Kopnina which stated that unfortunately few universities have recognised the advantages of strategically aligning the curriculum with SDGs. Overall, universities need to pay more attention to SDGs and carefully assess how much assistance they can provide to achieve their goals [58].

In addition, universities need to increase students' awareness by integrating climate change topics into educational curriculum and conducting awareness seminars on climate change, which was reiterated by the focus groups. Improving education on climate change had proved to increase awareness [11]. Moreover, universities worldwide had developed a climate change courses, which resulted in students having more awareness on climate change $[59,60]$.

Figure 6 shows that the majority of students agreed that it is necessary to integrate climate change and environmental issues to university curriculum. Moreover, students agreed that they need training and awareness sessions to help them understand best practices to reduce climate change (median $=4)$. The results were similar for female and male students since no significant different had been found between students' responses using Mann-Whitney $U$ test $(U=7007.5, p$-value $=0.9, C I=95 \%)$. This suggests that female and male students are aware of the seriousness of the matter and are interested in increasing their environmental awareness. The focus group had similar response towards integrating climate change and environmental issues into university curriculum. They strongly agreed that the university should add a compulsory course, which focuses on climate change. 
Table 10. Median of students' responses to source of climate change information.

\begin{tabular}{cccc}
\hline Source for Environmental Information & Median & Median Female Students & Median Male Students \\
\hline Internet & 4 & 4 & 4 \\
Social Media & 4 & 4 & 4 \\
News & 3 & 3 & 4 \\
Published Articles & 3 & 2 & 3 \\
University & 2 & 2 & 2 \\
Students' societies & 1 & 1 & 1 \\
\hline
\end{tabular}

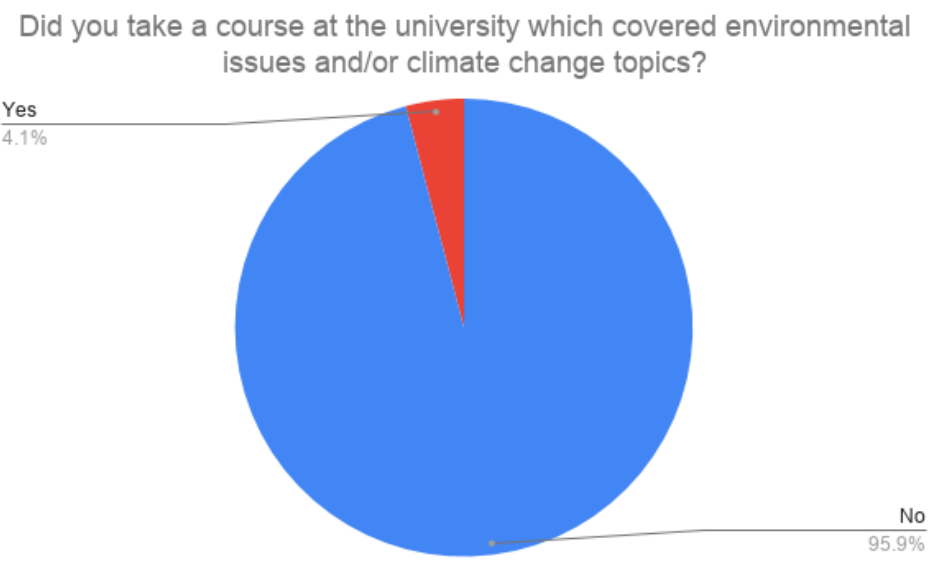

Figure 5. Percentage of students enrolled in a course covering environment or climate change topics.

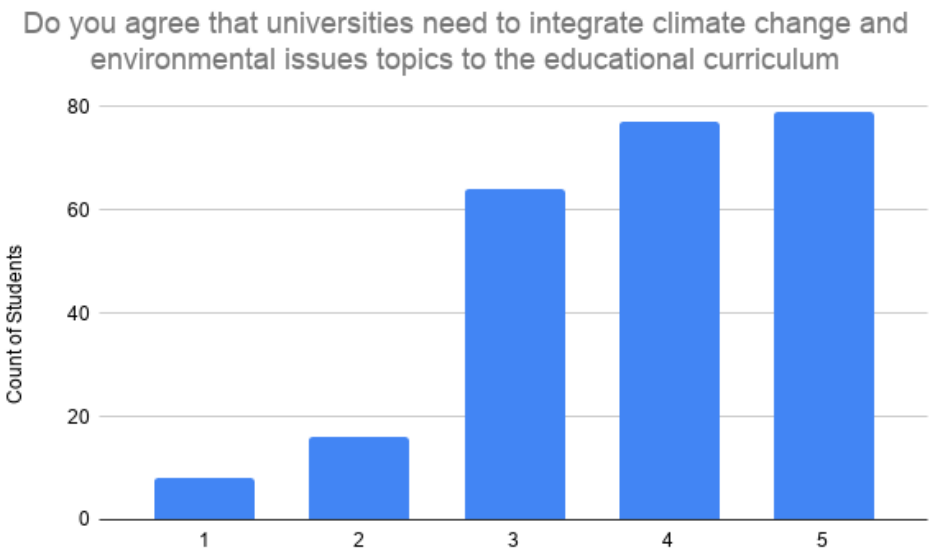

Figure 6. Students' agreement on integrating climate change to educational curriculum.

Even-though the educational curriculum has minimal integration of climate change topics, student societies hold several activities, which focus on various environmental and sustainability issues. Therefore, it is expected that these students have higher awareness regarding the climate change issues. In this study $37.9 \%$ of students were members of at least one student society at the university. The effect of students' societies on climate change awareness was examined by their performance in the quiz. Table 11 illustrates the overall performance mean for students who are members of student societies and non-members. The difference between the overall performance mean was measured using independent sample $t$-test. The results revealed that there is a significant difference in level of awareness between students who are members of societies and non-member students $(\mathrm{t}=-2.63, p$-value $<0.05, \mathrm{CI}=95 \%)$, with students in these societies having higher awareness. This reflects the importance of activities carried out by these societies. The results 
also revealed that student societies help female students improve their level of awareness (see Table 12). Female and male students who are members in societies had similar level of awareness $(\mathrm{t}=-0.2, p$-value $=0.87, \mathrm{CI}=95 \%)$. Moreover, a significant difference had been found between female students who are members and not members in students societies $(t=3.04, p$-value $<0.05, C I=95 \%)$. On the other hand, a significant difference had been found between male and female students who are not members in students' societies with males having higher level of awareness $(t=-0.2, p$-value $<0.05, C I=95 \%)$ and no significant difference had been found between male students who are members and not members in students' societies ( $\mathrm{t}$-value $=0.103712, p$-value $=0.92, \mathrm{CI}=95 \%$ ). The focus group agreed that societies help student members explore multidisciplinary topics and improve their problem solving and critical thinking skills. This helps students improve their awareness on several issues including climate change. The focus group also argued that culture contributes to the difference in level of awareness between female students who are members and non-members of students' societies. Female students find it difficult to explore and learn outside the university campuses. These societies provide them with a formal diverse educational entity in which they can explore several topics and enhance their skills. This consequently helps them improve their awareness on climate change.

Table 11. Effect of students' societies on students' level of awareness on climate change.

\begin{tabular}{cccc}
\hline Member of Student Society & Number of Students & Mean Performance & Standard Deviation \\
\hline Yes & 94 & 46.9 & 22.7 \\
No & 154 & 39.5 & 19.0 \\
\hline
\end{tabular}

Table 12. Effect of students' societies and gender on students' level of awareness on climate change.

\begin{tabular}{ccccc}
\hline Member of Student Society & Number of Students & Gender & Mean Performance & Standard Deviation \\
\hline Yes & 55 & Female & 46.6 & 24 \\
Yes & 39 & Male & 47.4 & 21 \\
No & 104 & Female & 36 & 19.0 \\
No & 50 & Male & 47 & 17 \\
\hline
\end{tabular}

The main results of the interviews with the two faculty deans confirmed that regular university programs do not include much knowledge about climate change, and they were not surprised that engineering students have higher knowledge than others and that female students enrolled in students' societies have higher awareness level than other females. As stated, engineering students tend to deal with multi-disciplinary topics and projects; therefore, widening their knowledge horizon. Furthermore, activities held by students' societies touch on several general topics, in addition to being related to main theme of the specific society. As for female students enrolled in these societies, they believe that due to cultural issues, female students find good opportunities to explore several subjects and interact with others through the activities held by these societies. Therefore, this would widen their horizon and general knowledge.

The vice president for academic affairs confirmed that the university is very much interested in applying as many as they can of the SDGs; therefore, posted them in several places on campus to spread awareness first; although the university recognises that much work is still needed in this regard at the university level. Furthermore, the university continuously reviews the "university required courses" and is interested in updating them in light of recent global developments. Recently, the university has formed a "21st century skills" committee; therefore, it is interested in including skills related to the SDGs for students and graduates. 


\section{Conclusions}

Climate change affects millions of people every year. It causes natural disasters, extreme weather patterns, and/or infectious diseases. Therefore, spreading climate change awareness becomes essential. Universities play an essential role in spreading environmental awareness. However, minimal research had been carried out to understand students ${ }^{\prime}$ levels of awareness and daily behaviour towards climate change, especially in developing countries. Therefore, this paper presents a study, which investigates the awareness level of An-Najah National University students, Palestine on climate change for the first time. This is also envisioned as a case study for developing countries.

The study was carried out in two stages on 448 undergraduate students. The first stage was a preliminary study that included 200 students and aimed to examine students' general interest in environmental topics and activities, which revealed that they had minimal interest in environmental topics and practices. The second stage, which was more detailed, focused on climate change and was conducted on 248 students taking into consideration gender, faculty and involvement in students' societies. This was supported by focus group sessions and interviews with top officials.

Qualitative and quantitative research methods were applied to the collected data and the results revealed that students' awareness levels were not satisfactory with females having lower awareness level. On the other hand, being an engineering student or a member in students' societies had a positive impact on students' level of awareness and practices, especially females. This was attributed to nature of engineering studies of being multi-disciplinary and project-based, and to the fact that students' societies provide amble opportunities to interact and broaden the knowledge horizon. The results revealed that female students who are enrolled in the engineering faculty or members of students' societies had a significantly higher level of awareness compared to female students who are enrolled in other faculties or not members of these societies. This was attributed to cultural issues such that female students get better opportunities through these societies to explore and interact with others on various topics.

The overall conclusion is that for An-Najah National University, which is considered as a typical Palestinian university, gender equality did not seem to be an issue; however, students in general had a low level of awareness on climate change regardless of gender or faculty. On the other hand, students' societies contributed positively towards enhancing female students' awareness level. The existing curriculum and the university do not contribute to spreading a satisfactory level of awareness among students.

Although the university has recently showed a clear interest in adopting the SDGs as part of its societal role and responsibility and to improve its international ranking; however, major efforts are still needed to spread the awareness among its students. Furthermore, the university has recently formed various university-level committees to improve its programs and students' attained skills. Therefore, this a golden opportunity for the university to reorient their programs and activities and offer students especially females opportunities to learn more about the SDGs including climate change. It is recommended that a university required course on climate change be introduced at the university level. Moreover, universities should support extracurricular activities held by student societies as these clearly contribute to enhancing students' skills and knowledge in various fields including environmental and climate change issues and proper practices.

In future work, this study will be applied across other universities in Palestine. In addition, several additional factors will be studied, such as the economic and political situation of the country, living place, and academic achievement. Moreover, a study will be carried out to examine the best practices to spread awareness of climate change among university students. 
Author Contributions: Conceptualisation, M.N.D. and K.A.-S.; methodology, M.N.D. and K.A.-S.; formal analysis, M.N.D.; writing-original draft preparation, K.A.-S.; writing-review and editing, M.N.D. and K.A.-S. All authors have read and agreed to the published version of the manuscript.

Funding: TARGET-This project has received funding from the European Union's Horizon 2020 research and innovation programme under grant agreement NO 741672.

Acknowledgments: The authors would like to thank RMEI and mainly Anastasia Zabaniotou, professor of Aristotle University and Leader of Gender Equality Working Group at RMEI for her support and cooperation throughout the research study. Moreover, the authors would like to thank Rayan Rajab, Hiba Alkurd and Hiba Ghanim who are enrolled in Critical Thinking and Research Skills course at the FEIT, An-Najah National University and helped in data collection.

Conflicts of Interest: The authors declare no conflict of interest.

\section{Appendix A. Climate Change Awareness Test}

1. Which gas contributes the most to climate change?

- $\mathrm{CO}_{2}$

- Nitrogen

- Oxygen

- Methane

2. How many acres of forests and woodlands are lost every year?

- 1 million

- 5 million

- 10 million

- More than 15 million

3. Which of the followings contribute more to climate change?

- Human activities

- Natural influences

4. Which of the following phenomena are likely to be caused by climate change?

- Desertification

- Floods

- Melting ice

- Heat waves

- Increase in heavy rain and snow

- Sea level rise

- Wildfires

5. Which of the followings are main causes of climate change?

- The use of fossil fuels (gas and petroleum) in transportation

- Deforestation for urbanisation

- The increase in agriculture and greenhouses

- Electricity production

- Animal farms (cows)

6. Do you know the difference between weather and climate?

- Yes

- Maybe

- No

7. How many people die annually due to climate change?

- Less than a thousand

- 1-5 thousand

- $\quad 10-100$ thousand

- More than 150 thousand 


\section{References}

1. Climate Change-Wikipedia. Available online: https://en.wikipedia.org/wiki/Climate_change (accessed on 18 November 2020).

2. Gul, A.; Topay, M.; Ozaydin, O. Against the threat of global warming, the importance of urban forest. In Proceedings of the International Davraz Congress, Isparta, Turkiye, 24-27 November 2009.

3. Ozbayrak, O.; Uyulgan, M.; Alpat, S.; Alpat, S.; Kartal, M. A research on high school students' knowledge related to global warming. Buca Eğitim Fakültesi Dergisi 2011, 29, 58-67.

4. Goal 4: Quality Education / UNDP. Available online: https://www.undp.org/content/undp/en/home/sustainable-developmen t-goals/goal-4-quality-education.html (accessed on 31 December 2020).

5. Chuku, C.A. Pursuing an integrated development and climate policy framework in Africa: Options for mainstreaming. Mitig. Adapt. Strateg. Glob. Chang. 2010, 15, 41-52. [CrossRef]

6. Jopp, R.; DeLacy, T.; Mair, J. Developing a framework for regional destination adaptation to climate change. Curr. Issues Tour. 2010, 13, 591-605. [CrossRef]

7. Tsai, C.H.; Wu, T.c.; Wall, G.; Linliu, S.C. Perceptions of tourism impacts and community resilience to natural disasters. Tour. Geogr. 2016, 18, 152-173. [CrossRef]

8. Pandve, H.T.; Deshmukh, P.R.; Pandve, R.T.; Patil, N.R. Role of youth in combating climate change. Indian J. Occup. Environ. Med. 2009, 13, 105. [CrossRef]

9. Al-Naqbi, A.K.; Alshannag, Q. The status of education for sustainable development and sustainability knowledge, attitudes, and behaviors of UAE University students. Int. J. Sustain. High. Educ. 2018, 19, 566-588. [CrossRef]

10. Trippl, M.; Sinozic, T.; Lawton Smith, H. The role of universities in regional development: Conceptual models and policy institutions in the UK, Sweden and Austria. Eur. Plan. Stud. 2015, 23, 1722-1740. [CrossRef]

11. Sanni, M.; Adejuwon, J.O.; Ologeh, I.; Siyanbola, W.O. Path to the Future for Climate Change Education: University Project Approach. In The Economic, Social and Political Elements of Climate Change; Springer: Berlin, Germany, 2011; pp. 693-702.

12. Wachholz, S.; Artz, N.; Chene, D. Warming to the idea: University students' knowledge and attitudes about climate change. Int. J. Sustain. High. Educ. 2014, 15, 128-141. [CrossRef]

13. Leal Filho, W. Communicating climate change: Challenges ahead and action needed. Int. J. Clim. Chang. Strateg. Manag. 2009, 6, 522011. [CrossRef]

14. Holtsmark, B. International cooperation on climate change: Why is there so little progress? In Handbook on Energy and Climate Change; Edward Elgar Publishing: Cheltenham, UK, 2013.

15. Leal Filho, W.; Shiel, C.; Paço, A.; Mifsud, M.; Ávila, L.V.; Brandli, L.L.; Molthan-Hill, P.; Pace, P.; Azeiteiro, U.M.; Vargas, V.R.; et al. Sustainable Development Goals and sustainability teaching at universities: Falling behind or getting ahead of the pack? J. Clean. Prod. 2019, 232, 285-294. [CrossRef]

16. Leal Filho, W.; Mifsud, M.; Molthan-Hill, P.; J Nagy, G.; Veiga Ávila, L.; Salvia, A.L. Climate change scepticism at universities: A global study. Sustainability 2019, 11, 2981. [CrossRef]

17. David, M.E. Women and gender equality in higher education? Educ. Sci. 2015, 5, 10-25. [CrossRef]

18. Aburaida, L.M. Obstacles facing rural women development in the Palestinian society: Nablus Governorate as a Case Study. J. Cult. Values Educ. 2020. [CrossRef]

19. Olarewaju, T.; Fernanado, J. Gender Inequality and Female Entrepreneurship in Developing Countries. In Decent Work and Economic Growth. Encyclopedia of the UN Sustainable Development Goals; Springer: Cham, Switzerland, 2020. [CrossRef]

20. Bjorn Andersson, A.W. Students' Understanding of the Greenhouse Effect, the Societal Consequences of Reducing $\mathrm{CO}_{2}$ Emissions and the Problem of Ozone Layer Depletion. J. Res. Sci. Teach. Off. J. Natl. Assoc. Res. Sci. Teach. 2000. [CrossRef]

21. Skamp, K.; Boyes, E.; Stannistreet, M. Global warming responses at the primary secondary interface 2. Potential effectiveness of education. Aust. J. Environ. Educ. 2009, 25, 31-44. [CrossRef]

22. Taber, F.; Taylor, N. Climate of Concern-A Search for Effective Strategies for Teaching Children about Global Warming. Int. J. Environ. Sci. Educ. 2009, 4, 97-116.

23. Kılınç, A.; Boyes, E.; Stanisstreet, M. Turkish school students and global warming: Beliefs and willingness to act. Eurasia J. Math. Sci. Technol. Educ. 2011, 7, 121-134. [CrossRef]

24. AbuQamar, S.; Alshannag, Q.; Sartawi, A.; Iratni, R. Educational awareness of biotechnology issues among undergraduate students at the United Arab Emirates University. Biochem. Mol. Biol. Educ. 2015, 43, 283-293. [CrossRef]

25. Freije, A.M.; Hussain, T.; Salman, E.A. Global warming awareness among the University of Bahrain science students. J. Assoc. Arab. Univ. Basic Appl. Sci. 2017, 22, 9-16. [CrossRef]

26. Moswete, N.M.; Manwa, H.; Purkitt, H. Perceptions of College Students towards Climate Change, Environmental, and Tourism Issues: A Comparative Study in Botswana and the US. Int. J. Environ. Sci. Educ. 2017, 12, 1175-1193.

27. Climate Change and Gender-Wikipedia. Available online: https://en.wikipedia.org/wiki/Climate_change_and_gender (accessed on 30 November 2020). 
28. Why Gender Matters in Climate Change Adaptation I International Institute for Sustainable Development. Available online: https://www.iisd.org/articles/gender-climate-change (accessed on 30 November 2020).

29. Climate Change I United Nations. Available online: https://www.un.org/en/sections/issues-depth/climate-change/ (accessed on 2 January 2021).

30. Climate Change and Gender Equality | United Nations Educational, Scientific and Cultural Organization. Available online: http:/ / www.unesco.org/new/en/natural-sciences/priority-areas/gender-and-science/cross-cutting-issues / climate-ch ange-and-gender-equality (accessed on 30 November 2020).

31. Gender and Climate Change IIUCN. Available online: https:/ / www.iucn.org/resources/issues-briefs/gender-and-climate-chan ge (accessed on 30 November 2020).

32. Löw, C. Gender and indigenous concepts of climate protection: A critical revision of REDD+ projects. Curr. Opin. Environ. Sustain. 2020, 43, 91-98. [CrossRef]

33. Zabaniotou, A. Towards gender equality in Mediterranean Engineering Schools through networking, collaborative learning, synergies and commitment to SDGs-The RMEI approach. Glob. Transit. 2020, 2, 4-15. [CrossRef]

34. Zabaniotou, A. New forms of social learning in mediterranean higher engineering education: Change lab for gender equality transformation, methodology, design principles. Sustainability 2020, 12, 6618. [CrossRef]

35. SPSS Software IBM. Available online: https://www.ibm.com/analytics/spss-statistics-software (accessed on 1 January 2021).

36. An-Najah National University: Sustainability. Available online: https://www.najah.edu/en/about/sustainability/ (accessed on 9 December 2020).

37. Birzeit University excels in UN Sustainable Development Goals / Birzeit University. Available online: https:/ / www.birzeit.edu / en/news/birzeit-university-excels-un-sustainable-development-goals (accessed on 9 December 2020).

38. Impact Rankings 2019 by SDG: Climate action I Times Higher Education (THE). Available online: https://www.timeshighereduca tion.com/rankings/impact/2019/climate-action\#!/page/0/length/25/sort_by/rank/sort_order/asc/cols/undefined (accessed on 7 December 2020).

39. Sustainability Report 2019_2020. Available online: https://www-cdn.najah.edu/media/filer_public/71/2f/712f4d05-102d-415b -99ba-bad06a9e95f7/sustainability_report_2019_2020.pdf (accessed on 9 December 2020).

40. An-Najah National University: Policies. Available online: https://www.najah.edu/en/about/policies/ (accessed on 22 January 2021).

41. RMEI Gender Equality Policy Statement. Available online: https://www-cdn.najah.edu/media/filer_public/fe/30/fe307711-4 019-4eaa-837d-e99b592e1a14/rmei_gender_equality_policy_statement.pdf (accessed on 22 January 2021).

42. IEEE-IEEE Women in Engineering. Available online: https://www.ieee.org/membership/women/index.html (accessed on 1 January 2021).

43. ArabWIC. Available online: http://www.arabwic.org/ (accessed on 1 January 2021).

44. Homepage-Girls in Tech. Available online: https:/ / girlsintech.org/ (accessed on 1 January 2021).

45. Shahid, Z.; Piracha, A. Awareness of climate change impacts and adaptation at local level in Punjab, Pakistan. In Balanced Urban Development: Options and Strategies for Liveable Cities; Springer: Cham, Switzerland, 2016; pp. 409-428.

46. United Nations Development Programme. Fighting Climate Change: Human Solidarity in a Divided World; Springer: Cham, Switzerland, 2007.

47. Shi, J.; Visschers, V.H.; Siegrist, M.; Arvai, J. Knowledge as a driver of public perceptions about climate change reassessed. Nat. Clim. Chang. 2016, 6, 759-762. [CrossRef]

48. Azapagic, A.; Perdan, S.; Shallcross, D. How much do engineering students know about sustainable development? The findings of an international survey and possible implications for the engineering curriculum. Eur. J. Eng. Educ. 2005, 30, 1-19. [CrossRef]

49. Lee, T.M.; Markowitz, E.M.; Howe, P.D.; Ko, C.Y.; Leiserowitz, A.A. Predictors of public climate change awareness and risk perception around the world. Nat. Clim. Chang. 2015, 5, 1014-1020. [CrossRef]

50. Pruneau, D.; Khattabi, A.; Demers, M. Challenges and Possibilities in Climate Change Education. Online Submiss. 2010, 7, 15-24.

51. Sellmann, D. Environmental education on climate change in a botanical garden: Adolescents' knowledge, attitudes and conceptions. Environ. Educ. Res. 2014, 20, 286-287. [CrossRef]

52. Skamp, K.; Boyes, E.; Stanisstreet, M. Beliefs and willingness to act about global warming: Where to focus science pedagogy? Sci. Educ. 2013, 97, 191-217. [CrossRef]

53. Kollmuss, A.; Agyeman, J. Mind the gap: Why do people act environmentally and what are the barriers to pro-environmental behavior? Environ. Educ. Res. 2002, 8, 239-260. [CrossRef]

54. Williamson, K.; Satre-Meloy, A.; Velasco, K.; Green, K. Climate Change Needs Behavior Change: Making the Case for Behavioral Solutions to Reduce Global Warming; Rare: Arlington, VA, USA, 2018.

55. Dietz, W.H. Climate change and malnutrition: We need to act now. J. Clin. Investig. 2020, 130. [CrossRef]

56. Caulfield, B. Estimating the environmental benefits of ride-sharing: A case study of Dublin. Transp. Res. Part D Transp. Environ. 2009. [CrossRef]

57. Shaaban, K. Why Don't People Ride Bicycles in High-Income Developing Countries, and Can Bike-Sharing Be the Solution? The Case of Qatar. Sustainability 2020, 12, 1693. [CrossRef]

58. Kopnina, H. Teaching sustainable development goals in The Netherlands: A critical approach. Environ. Educ. Res. 2018, 24, 1268-1283. [CrossRef] 
59. Rooney-Varga, J.N.; Brisk, A.A.; Adams, E.; Shuldman, M.; Rath, K. Student media production to meet challenges in climate change science education. J. Geosci. Educ. 2014, 62, 598-608. [CrossRef]

60. Monroe, M.C.; Plate, R.R.; Oxarart, A.; Bowers, A.; Chaves, W.A. Identifying effective climate change education strategies: A systematic review of the research. Environ. Educ. Res. 2019, 25, 791-812. [CrossRef] 